plague, famine, and war ; secondly, it caused very little attention to be paid to their positions among the stars, so that in several cases this is far more precisely stated in Chinese and Japanese records than in European.

Tycho Brahe made it clear, by the absence of appreciable parallax, that comets were at least several times more remote than the moon, and so restored them to the status of heavenly bodies. When Kepler, from a study of Tycho's observations, demonstrated the elliptical character of the planetary orbits, the idea occurred independently to Hevelius, Borelli, Löwer, and Dörfel that comets might also have elliptical paths of a much more elongated character than those of the planets, so that they remained invisible for the greater part of their period of revolution. These ideas remained merely conjectural until Newton had demonstrated that the law of universal gravitation, varying inversely as the square of the distance, gave a full explanation of the lunar and planetary movements, and indicated the possibility of motion in conic sections of any eccentricity.

Thus at last it became possible to calculate the orbits of comets. Many difficulties arose in the practical work, owing to the roughness of the observations and the small arc covered by them. It has needed long experience and the continued work of a long series of mathematicians to reduce the calculation to its simplest form. At first it offered great difficulties even to Newton. He was unfortunate in choosing as one of his examples the great comet of $1680-81$, which had the very small perihelion distance $0 \cdot 006$. It will be remembered that the ' daylight' comet of January 1910, which also had a small perihelion distance, baffled the orbit computers in the early days of its apparition. So Newton is stated to have lost two months in 1685 in attempting to deduce the orbit of the 1680 comet, though he ultimately succeeded in obtaining a tolerable result, and in proving that the morning comet of November 1680 was the same body that was seen in the evening in the following January.

Newton has freely acknowledged in the "Principia" the great debt that he owed to Halley for carrying the cometary computations much further than he himself had the leisure or inclination to do. As is well known, Halley took up the application of the law of gravitation to comets with the greatest enthusiasm, and calculated the orbits of 24 of them from observations extending over two centuries, which he had collected with much diligence. $\mathrm{He}$ was rewarded for this great labour by the discovery of the periodic comet that bears his name, which he found to have appeared in 1456, 1531, 1607, 1682. He thus reduced these wandering bodies to recognised members of the solar system, his work being afterwards vindicated by the return of his comet in 1759 , in almost exact accordance with his prediction. Thus it may be said that Newton's discovery, vastly useful as it was for the prediction of lunar and planetary motions, produced a still more revolutionary advance in the world of comets.

\title{
Dwelling-places, Portraits, and Medallic Illustrations of Newton.
}

$\mathrm{T}^{\mathrm{H}}$ HE particulars concerning the birth and upbringing of Newton, as well as his domiciliary situation and circumstances while at Cambridge, are so well known that they need no further narration. But his eventful and full life in London, in east and west, covering a period of thirty years, and when in the zenith of fame, may perhaps receive some attention. It suffices, as a preliminary, to recall that, in 1701 , Newton resigned the Lucasian chair at Cambridge. He had earlier (1696) been appointed Warden of the Mint, and later (1699) Master.

\section{DWELLING-PLACES}

Towards the close of 1697 , Newton went into residence in Jermyn Street, where he stayed until 1710. From here he wrote to Flamsteed, under date 1698 , whilst Bentley addressed a letter to him, so late as 1709, in this wise: "Sir Isaac Newton, at his house in Jermin Street, near St. James's Church, London." After a short stay in Chelsea, "near the College," Sir Isaac removed about the end of September 1710 to a large and commodious house in St. Martin's Street, Leicester Fields, occupying this as tenant during the rest of his life. Actually, however, he ceased to live in it from 1725, for, owing to indifferent health, he had gone into quarters at Kensington, dying there in 1727. It was in that year that his name was erased from the books of his former parish. The identification of the house in Kensington where Newton lived was established and recorded in 1852 by Mr. Joseph Jopling, an architect, who thereupon received the thanks of the president and council of the Royal Society. It was probably in early days within sight of Kensington Palace.

Newton had procured (with the active assistance of Wren), in the very year of the acquisition of a new domicile for himself, a home for the Royal Society in Crane Court, Fleet Street. Possibly, in determining this abode, he was mindful of the claims imposed upon his time by the weekly meetings of the Society. He would not have far to go from Leicester Fields to Crane Court.

In St. Martin's Street Newton lived in excellent style, kept a carriage, and maintained an establishment of three male and three female servants. Ample hospitality was proffered without ostentation or vanity, his niece, the accomplished Catherine Barton, presiding at the philosopher's table. She married John Conduit in 1717, who, in later years, wrote "nobody ever lived with him but my wife, who was with him near twenty years." Eminent foreigners visiting London were always sure of a warm welcome. Newton built a small observatory on the roof of his house. At the moment of writing, the foundations of a spacious new building are in progress on the site of the

No. 2995, VoL. 119] 
derelict residence of Newton. It may be hoped that a suitable commemorative tablet (more appropriate at least than that in Jermyn Street) will be affixed in due time.

Several engravings of the St. Martin's Street house are extant. There is one in the European Magazine for 1811. In Smith's "Historical and Literary Curiosities" is an engraving (published 1836) showing the interior of the observatory ; and another of the house itself (published 1837). Long after Newton's death, a story got into circulation that the house was at one time taken by a foreigner, who built an observatory at the top, storing there some obsolete apparatus. He advertised the place as being on view in the state left by Newton, and many visitors were imposed upon. The circumstance is alluded to by J. T. Smith in "An Antiquarian Ramble in the Streets of London" (1846), and by the Rev. W. G. Humphry, sometime Vicar of St. Martin-in-theFields, in a pamphlet issued in 1857 .

\section{Portraits.}

The lineaments of Newton have been conveyed to canvas, and thence to posterity, by many celebrated painters-notably by Kneller, Vanderbank, Thornhill, Charles Jervas, and Seeman. Many engravings from these personal studies have been produced by masters in their art; in addition, there are innumerable woodcuts. In the subjoined notice, while space permits only brief reference to selected examples of portraiture, some idea of the manner and time of presentment may, however, be gathered.

The earliest authenticated portrait of Newton is that by Sir Godfrey Kneller (deceased 1723) in the possession of the Earl and Countess of Portsmouth, at Hurstbourne Park. It represents him with long natural hair and shirt open at the neck. Painted in 1689, it shows Newton at the age of thirty-eight. A faithful engraving of this portrait was made by T. O. Barlow, R.A.

There is also a fine study of Newton by Kneller, painted in 1720 , at Petworth House, Sussex, in the ownership of Lord Leconfield. The philosopher is represented nearly whole length, seated in an elbow chair, in wig, looking to right, the right arm resting on an abutment; in left hand, a glove. The picture was engraved in stipple by W. T. Fry for Edmund Lodge's "Portraits of Illustrious Persons" (folio 1831).

The three-quarter canvas by John Vanderbank in the National Portrait Gallery, St. Martin's Place, is of high interest. Newton, with flowing hair and white neckerchief, is represented seated in a highbacked chair, one arm resting. An open book on a table is before him, a leaf of which he holds. In the background is a globe. The legend appended describes him as "The Great Philosopher; Discoverer of the laws of gravitation, and of the nature of light and colour. Author of the Principia." The pose of the head, drawing of the hands, and fine colouring of the face, arrest attention. The whole composition is in harmonious balance. We know that Vanderbank's pencil received the stimulus of a long and faithful attachment to Newton.

At the Royal Society, holding place of honour in the meeting-room, over the president's chair, is John Vanderbank's impressive portrait of Sir Isaac, painted in 1726, when Newton was eighty-four years old. It is nearly whole-length, and the subject is seated in an armchair, in velvet gown, with long white neckerchief and white ruffles at the wrists. A mezzotint from the portrait was engraved by $\mathbf{J}$. Faber, jun. The picture was presented to the Royal Society in 1841 by Mr. C. B. Vignoles, F.R.S.

Mention must not be omitted here of Vanderbank's portrait of Newton, painted in the year previous to the foregoing. The original is at Trinity College, Cambridge. An engraving from it forms the frontispiece to the "Principia," third ed., 1726.

The Royal Society possesses also a portrait by Charles Jervas, given in 1717 by Newton himself. No particulars of this gift, by letter, exist. Doubtless it hung in Crane Court. The painter was sometime a pupil of Kneller.

Martin Folkes, often Sir Isaac's deputy in the chair in his declining health, gave the Society a portrait which is signed by Vanderbank.

One of the most interesting Newtonian portraits is that by Enoch Seeman, painted for Thomas Hollis, F.R.S. It is recorded in Hollis's "Memoirs" ( 2 vols. 1780 , privately printed, many plates) that on Oct. 29, 1761, he presented to Trinity College, Cambridge, an original portrait of Sir Isaac Newton "painted in the year 1726." Comment is made that "Mr. Hollis's expenses this year [1762] to artists in the painting and engraving way appear to have been very considerable, particularly to Signor Cipriani ; and likewise to Mr. MacArdell for a mezzotint of Sir Isaac Newton from the portrait presented to Trinity College." This engraving, it should be said, was published in Vol. 2 of the "Memoirs," and bears a quotation from Voltaire. Its rarity has led to the acquisition of the "Memoirs" for the purpose of abstraction of the engraving. Instances are within the writer's knowledge. A copy of the "Memoirs" exists in the library of the Society of Antiquaries, but we look in vain for the mezzotint. On the other hand, a copy in the Royal Institution is perfect in all respects. James MacArdell was a brilliant craftsman who executed plates of many persons of distinction. He died in London in 1765.

In the drawing-room of the Master's Lodge, Trinity College, Cambridge, is a half-length portrait of Newton, in gown, executed in 1710 by that eminent artist James Thornhill (knighted 1720), who was court sergeant-painter in Newton's London days. It was bequeathed to the College by Dr. Richard Bentley. Writing to Newton in 1709 , Bentley says: "I hope my picture at Thornhill's will have your last sitting before you leave the town." It was engraved as an oval by J. Simon.

The Countess of Portsmouth kindly supplies the information that at Hurstbourne Park, in addition to the Kneller of 1689 , and one of 1702 , as well as a head by Thornhill, the family possess a small sketch, believed to be by Kneller, a bust by

No. 2995, VoL. 119] 
Roubiliac, and a death mask of Newton, the last named presented by Mr. Alfred Gilbert, R.A.

\section{Medallic Illustrations.}

Numerous medals and tokens were in circulation at home and abroad after Newton's death. Most of them bear the bust of Newton; on a reverse of one is a representation of Newton's monument in Westminster Abbey. A medal (it is rare), designed by James Roettier in 1739, shows the bust of Newton, and for reverse, science, personified as a female, with wings, is seated on a rock, holding a diagram of the solar system. The Royal Astronomical Society's gold medal bears Newton's head. This yearly gift replaces an earlier type by George Mills, awarded for the first time in 1822, but superseded in 1831. On the reverse was an inscription taken from verses by Halley prefixed to the first edition of the "Principia." The Royal Society's annual Royal Medal perpetuates Newton through a reproduction on the reverse of Roubiliac's statue in the ante-Chapel of Trinity College, Cambridge. McGill University, Montreal, awards a medal which carries a head of Newton. The list admits of extension.
T. E. JAMES.

\section{News and Views.}

THE Grantham commemoration of Newton on Mar. 18-20 was a brilliant success and reflected much credit on the Yorkshire Branch of the Mathematical Association and its able and active president, Prof. S. Brodetsky. It would be difficult to say which was the best-arranged part of the programmethe scientific meeting, the visit to the Manor House at Woolsthorpe, the dinner, or the service in Grantham Church. All went off without the smallest hitch. But there can be no doubt as to the most impressive part. The gathering in the magnificent church, crowded in every corner, the bright robes. and the band of scholars, the hearty singing of the finest old psalms and hymns, the exquisite choice of passages for reading, above all, the superb sermon of the Bishop of Birmingham, made a profound impression. The end fitly crowned the work of commemoration, and those who came from a distance--some 150 of them-dispersed in the afternoon full of gratitude to Prof. Brodetsky, Mr. A. B. Oldfield, and other devoted members of the Mathematical Association, as well as to Mr. Christopher Turnor, Sir Charles Welby, the Mayor of Grantham, and others who generously provided hospitality for some of the visitors.

Celebrations are now of almost monthly occurrence, and some people may think there are too many of them. Happily in the case of the Newton commemoration there was no doubt from beginning to end, and the concurrence of the many sides of his marvellous character was well brought out. Even the weaker points of his humanity found their recording angels in the comparative privacy of the afterdinner speeches. His interest in the 'stinting' of the farmer on his Manor of Woolsthorpe and in the actual working of the estate his action at the Mint which restored the guinea to its face-value, and his own operations in the share market, these were probably the sides of his work which were new to the largest number of the audience. To these should be added Dr. Barnes's discovery of the state of his theological beliefs and the probable reason why he abstained from taking orders. Altogether, the occasion was worthy of its subject, and stands out as a very moving and instructive commemoration. For the purposes of education such a function has a double aspect, and it is impossible to say which is more valuable. On one hand, it introduces a large public to the work of men whose thought in its entirety is inaccessible to most, but who have a human and a beneficent quality which all can appreciate. On the other hand, it turns the thoughts of men of science to the human and historical aspects of their subject. If we think of the great founders, we are bound to fit them into their place in the evolution of thought, to regard them, not only as real human beings like ourselves, but also as steps in the upward march of the human spirit.

Strveral telegrams and other messages were read at the scientific meeting and the dinner. Prof. Einstein sent a letter to Dr. Jeans, secretary of the Royal Society, but it was unfortunately not handed to Dr. Jeans in time to be read. We are glad, however, to be able to publish a translation of the letter. "More than any other people," wrote Prof. Einstein, " you Englishmen have carefully cultivated the bond of tradition and preserved the living and conscious continuity of successive generations. You have in this way endowed with vitality and reality the distinctive soul of your people and the soaring soul of humanity. You have now assembled in Grantham in order to stretch out a hand to transcendent genius across the chasm of time, and to breathe the air of the precincts where he conceived the fundamental notions of mechanics and of physical causality. All who share humbly in pondering over the secret of physical events are with you in spirit, and join in the admiration and love that bind us to Newton. What has happened since Newton in theoretical physics is the organic development of his ideas. Force became independent reality to Faraday, Maxwell, and Lorentz, and then went over into the conception of the field. The partial differential equation has taken the place of the ordinary differential equation used by Newton to express causality. Newton's absolute and fixed space has been converted by the theory of relativity into a physically vital frame. It is only in the quantum theory that Newton's differential method becomes inadequate, and indeed strict causality fails us. But the last word has not yet been said. May the spirit of Newton's method give us the power to restore unison between physical reality and the profoundest characteristic of Newton's teaching--strict causality."

No. 2995, VoL. 119] 